\title{
The Differential Effects of Foreign Investments on Sectoral Growth
}

\author{
Cheng HuiFang, Agbanyo George Kwame* \\ School of Economics, Zhejiang University of Technology,Hangzhou, China \\ *Corresponding Author.
}

\begin{abstract}
Previous studies on the effect of FDI on sectoral growth are far from reaching a consensus. This paper, using a panel data of 35 countries between 1990-2019, aims at investigating the differential effects of foreign direct investment modes of entry into the economic sectors. Through the systems generalized method of moments methodology, this study found that the impact of foreign investment on growth corresponds directly with the absorptive capacity of the host country. Meanwhile, M\&A is a better economic booster than greenfield investment. The results also suggest that foreign investment is a significant agent of economic growth in the service sector, relatively weak in the manufacturing sector and insignificant in the agriculture sector. Also, M\&A seems to spillover more easily than greenfield across sectors, and natural resources are not very good channels to transmit foreign investment into economic growth.
\end{abstract}

Keywords: FDI, agriculture, manufacturing, service sectors, economic growth.

\section{Introduction}

FDI is known to be a major medium of knowledge and technology transfer beneficial to economic growth both for developing and developed countries. Apart from technology and knowledge transfer, FDI channels management processes, capital formation as well as research \& development (R\&D) [1]. In his studies on Sub-Saharan Africa (SSA) he found that these externalities and the pivotal stimulants for economic growth in the host nation are based on the growth theory's emphasis on technology, efficiency and productivity. Empirical studies show that FDI positivelyaffect the economy at an aggregate level no matter the sectors within which the FDI goes or the types of FDI it might be. According to him, the benefits accrued might differ from sector to sector. Meanwhile, there is evidence that efficiency and market-seeking FDI tend to cause more growth than resource-seeking FDI since resource FDI is mainly extractive in nature and there is a level of adverse effects of the natural resource on the economy while efficiency and market FDI are targeted towards the industrial sector [2]. His finding is consistent with Hirschman, who found that not all sectors have the same capacity to absorb new technology or to link up with the rest of the economy to accrued the maximum benefits from foreign transfer.

Considering the amount of FDI inflow to Africa over the years, the question worth asking and investigating is what kind of investment is the best fit for Africa's economic emancipation? This question remains unresolved despite the amount of work done in this regard recently [2,3]. The majority of studies on FDI in Africa generally focus on the aggregate economic level, meanwhile, the sectoral level effects have not been thoroughly explored. In addition, a study on FDI on the aggregate level is not instructive and obscures the channels FDI affects economic growth at the sectoral level. For instance, a study by Alfaro explained that due to the negligiblebenefits from FDI on the agriculture sector, it has a negative impact. In Africa, Dlamini\& Fraser discovered a one-way causality impact betweenFDI and agricultural sector growth, with agricultural sector growth attracting a lot of FDI but no FDI increasing agricultural growth. According to published studies [3], both the manufacturing and the services sector have a positive association with FDI inflow. The impact of FDI on economic growth necessitates a far more sophisticated and in-depth examination.

ISSN: 0010-8189

(c) CONVERTER 2021

www.converter-magazine.info 
Because the regression equation is dynamic in nature, this analysis used system-GMM estimation to take care of the country-specific effect, which cannot be handled by country dummies. It also takes care of the possible endogenous problem between some explanatory variables caused by simultaneity bias.

This study is developed through the following sections. After the introduction, the second sectionpresents an aggregate of FDI effect on sectoral economic growth in Africa. A literature review related to the dynamics of FDI impact on African economic development is reported in section 3. In Section 4 we describe of the methodology and the data used for the research. Section 5 presents and analysis the results. In Section 5 there is the robust check analysis. Section 7 sets out the conclusions of the research.

\section{Literature Review}

The FDI-sectoral growth relationship is not very prominent in literature as compared to the aggregate level studies. Works on the relationship between foreign investment and economic growth reveal that the impact of FDI varies by sector, with favorable effects recorded in the manufacturing sector and negative effects for the agricultural sector. FDI through the stock of human capital has a strong influent on themanufacturing sector. Technological know-how and new process transfer in the FDI host country occurs primarily in the manufacturing sector with the most intensive linkage activities [5]. However, FDI is known torecord a stronginfluence on the growth of the manufacturing sector in case of resource (electricity) availability. Their main finding was, on one hand, FDI inflows had a beneficial influence though insignificant on the manufacturing sectorin terms of capital accumulation and technology transfer; on the other, a substantial but negative link of FDI with aggregate economic growth. Besides, the improvement of service quality via FDIexert a positive impact on other sectors' performance like business and producer services with impacts seen throughout that economy [3]. The previous belief that there is no transfer of new technology in the service sector has altered when "soft" technology is broadly defined to include skills and knowledge, material, organizational and information processes $[5,6]$.

Theoretically, FDI has potential economic benefits $[7,8]$. Meanwhile, Basu and Guariglia discovered a strong association between manufacturing growth and FDI [3], but a negative relationship between agricultural growth and FDI. According to them, FDI industrializes the host country, making the agricultural sector less important and reducing the agricultural sector's share in economic growth. The leakages and spillovers between local and foreign firms become limited in the agriculture sector and as a result, restrict the influence of agriculture FDI in causing economic growth. To find a study that investigated the effect of FDI on the agriculture sector separately is difficult. Agriculture FDI's impact on economic growth through technology spillover on county case studies in developing countries had shown mixed results [9]. There is a limited transfer of technology by agriculture MNEs in developing countries [10], there is a positive productivity-enhancing technology spillover in Egypt with value-added from Agriculture FDI. But Massoud reports a contrary result on in Agriculture sector in Egypt. According to his study, Agriculture FDI inflow hurts value-added growth and output growth. But, Empirical studies on the effect of agricultural FDI on economic growth prove to be inconclusive. Meanwhile, many recent types of research have underlined the challenge of lack of reliable agriculture data especially in the developing worldand in Africa $[7,8]$.

In many empirical studies, absorptive capacity-the extent to which the FDI host country is able to adapt and implement incoming new technology-is proved to be the economic growth factor in the host country [11,12]. There is a minimum threshold of human capacity as an indicator of absorptive capacity is needed in the host country for FDI to ignite the growth process [12]. On one hand, while some studies have found absorptive capacity as a catalyst for economic growth, on the other hand, many other results hold a contrary view by rejecting this conditionality [13]. In the same way, [14] rejected the conditionality in the case of Arab nations as well as [15] in the case of African countries.

A hypothesis derived from [16] to research on the heterogeneity of technology spillover across advanced countries employing the endogenous threshold regression techniques with a sample data of 57 developing countries from 2970-1998. It suggests that high standards of institutions in a host country determine equally higher per capita growth rates. Gui-Diby[4] found a differential effect of FDI over the data in Africa, thus from 1980-1994 FDI effect on economic growth was negative and significant while from 1995-2009 FDI positively affected growth. He used a system-GMM technique for the analysis. According to Abloyor et al. [2], FDI alone had a negative impact on economic growth in Africa, but the inclusion of domestic capital transformed FDI's impact into a substantial and

ISSN: 0010-8189

(C) CONVERTER 2021

www.converter-magazine.info 
positive one. They examined the impact of FDI on economic growth in 14 African nations using a GMM-instrumental variable technique using data from 1990 to 2007. Adams and Opoku[1] used the GMM estimation technique to study 22 SSA countries and found that only the presence of strong restrictions in the credit and labor markets causes FDI to have a favorable influence on economic growth.

In fact, while there is a wealth of literature on the impact of FDI on economic growth, research on the impact of FDI on growth in African economic sectors is scarce. Furthermore, there are essentially no indications of the forms of FDI inflow on sectoral growth, particularly in Africa. As a result, this study seeks to determine, first, the influence of FDI on sectoral growth and, second, the effect of FDI modes on sectoral growth.

\section{Research Methodology}

\subsection{Data and fundamentalanalysis.}

For this study, a yearly data from 35 African nations was sourced from the World Bank's World Development Indicators (WDI) and the United Nations Conference on Trade and Development from 1990 to 2019. The data failed to include all African countries because of the serious lack of data in some countries. According to the UN definition, Africa has 54 countries, but the sample of this study is comprised of 35 countries. We proxied economic growth using real GDP growth rate based on previous empirical works[17]. FDI is defined as the summation of equity capital, reinvestment earnings, and other long- and short-run capital from foreign investors recorded by the reporting countries. Mergers and acquisitions of local enterprises by a foreigner with higher than $10 \%$ equity capital are referred to as cross-border mergers and acquisitions. MNCs can engage in FDI through greenfield investments or mergers and acquisitions, in theory. According to the UN, net FDI is the addition of greenfield investment and mergers and acquisitions. Greenfield investment is calculated by the difference between total FDI and M\&As in a country.We avoided this method and rather employed the recent UNCTAD data of greenfieldFDI because the contrasted greenfield data is potentially inaccurate [6].For the sectoral analysis, first is the diagnosis of sectoral growth and sectoraltransmission channels. To measure growth in the agriculture, industry and service sectors respectively, this study employed the sectoral value addition in the various sectors. The sectoral transmission channel of FDI relies on three sectors which are the agriculture, manufacturing and service sectors. The value-added of the agriculture sector is the net output of the sector minus intermediate inputs out of the sum up of all outputs. The industry Value added is the net output minus the intermediate of value addition form of mining, construction, electricity, water and gas. Wholesale and retail trade (including hotels and restaurants), transportation, and private and public services are all included in the service sector value added (education, health care, and real estate). Every variable is calculated as a percentage of GDP.

For this study, FDI flow is preferred over FDI stock. While FDI stock is the (revalued) accumulation of previous flows, flows are the present transactions occurring over a certain time period t. Because they both create equity capital holdings at the conclusion of the term, FDI stock combines equity capital and reinvested earnings into a single category. While flow data may be calculated as the sum of all transactions over a certain time period, stock data is more difficult to calculate since it raises the issue of how to value assets purchased in the past. The assets held by the direct investor in the host economy must be revalued throughout the year. This comprises market value changes (price change), changes in asset value due to exchange rate fluctuations (values are generally stated in US-\$), and other adjustments such write-downs and reclassification. All of this results in changes. This illustrates the fact that FDI flows are rarely equal to the first difference in FDI stocks. When stock data is unavailable, summing capital flow data can be used as a rough approximation to fill in the gaps, albeit this does not account for non-transactional changes caused by exchange rate and price changes in a given year. The special scenario when there are no other options is an exception.

For a broader and comprehensive analysis, specific explanatory variables were incorporated into the model. Firstly, to evaluate for the influence of human capital on FDI spillover in the host nation, human capital is incorporated in the equation as the degree of education in the host country. The rate of secondary education is used as a proxy. Secondly, domestic capital accumulation investment is included to control for the domestic investment impact rate on growth apart from investment of exogenous impact of FDI on growth. It also allows for a comparison between the contribution of two investment sources (foreign and domestic) to the growth process. Domestic capital is proxied by the gross domestic fixed capital formation of GDP. These two variables are considered as major absorptive capacities

ISSN: 0010-8189

(C) CONVERTER 2021

www.converter-magazine.info 
in the host country. Thirdly, technology level is included in the equation as the level of technology in the host country to control for the influence of technology on FDI spillover in the host country. It is proxied by the rate of technology gap. Econometrically, technological gap can be quantified by the output level of the more developed country compared with that of the less developed country I [18].

$$
\mathrm{TG}_{i t}=\frac{\mathrm{y}_{\text {lead }}}{\mathrm{y}_{\text {it }}}=\operatorname{Iny}_{\text {lead }}-\operatorname{In} \mathrm{y}_{\text {it }}
$$

$\mathrm{y}_{\text {lead }}$ representing the country leading with a higher FDI outflow.

Table 1 Descriptive Statistics

\begin{tabular}{|c|c|c|c|c|c|c|c|c|c|c|c|c|c|c|c|}
\hline & GRW & FDI & M\&A & GF & Agric & Indus & Serv & DCap & HCap & TGap & Infra & Lab & NRes & PStab & GExp \\
\hline Mean & 3.805 & 3.139 & 0.616 & 8.632 & 2.849 & 3.764 & 3.845 & 28.362 & 21.785 & -4.293 & 3.390 & 0.053 & 10.641 & 13.837 & -0.605 \\
\hline Maximum & 15.006 & 27.789 & 13.613 & 90.876 & 17.137 & 52.191 & 14.261 & 90.758 & 52.869 & -0.754 & 97.139 & 0.187 & 51.852 & 33.636 & 1.019 \\
\hline Minimum & -11.480 & -1.245 & -1.233 & 0.000 & -7.961 & -17.057 & -10.784 & 0.000 & 1.509 & -6.188 & 0.019 & 0.002 & 0.007 & 0.873 & -3.177 \\
\hline Std. Dev. & 3.237 & 4.279 & 1.674 & 13.062 & 3.537 & 6.713 & 3.514 & 22.064 & 8.381 & 1.018 & 9.926 & 0.040 & 9.311 & 5.494 & 0.866 \\
\hline Skewness & -0.899 & 3.108 & 4.846 & 3.503 & 0.558 & 2.392 & -0.350 & 0.955 & 0.802 & 0.698 & 7.003 & 0.639 & 2.028 & 0.296 & -0.410 \\
\hline Kurtosis & 7.720 & 14.646 & 31.205 & 17.787 & 6.510 & 19.833 & 4.142 & 3.235 & 4.464 & 3.378 & 58.803 & 2.583 & 7.773 & 3.472 & 2.958 \\
\hline \multicolumn{16}{|l|}{ Percentiles } \\
\hline $25 \%$ & 0.750 & 1.784 & 0.000 & 0.709 & 12.511 & 28.570 & 6.849 & 11.502 & 3.270 & 39.010 & -1.273 & & & -1.273 & \\
\hline $50 \%$ & 2.330 & 3.850 & 0.096 & 1.738 & 20.651 & 41.749 & 12.955 & 19.442 & 17.244 & 56.370 & -0.410 & & & -0.410 & \\
\hline $75 \%$ & 5.974 & 5.631 & 0.509 & 4.437 & 28.210 & 49.409 & 17.063 & 24.869 & 36.607 & 77.574 & 0.033 & & & 0.033 & \\
\hline No. of obs & 163 & 163 & 163 & 163 & 163 & 163 & 163 & 163 & 163 & 163 & 163 & 163 & 163 & 163 & 163 \\
\hline \multicolumn{16}{|l|}{ Correlations } \\
\hline GRW & 1.000 & & & & & & & & & & & & & & \\
\hline FDI & 0.329 & 1.000 & & & & & & & & & & & & & \\
\hline M\&A & 0.110 & 0.350 & 1.000 & & & & & & & & & & & & \\
\hline GF & -0.055 & -0.156 & 0.032 & 1.000 & & & & & & & & & & & \\
\hline Agric & 0.517 & 0.025 & 0.080 & -0.088 & 1.000 & & & & & & & & & & \\
\hline Manu & 0.705 & 0.227 & -0.008 & -0.074 & 0.329 & 1.000 & & & & & & & & & \\
\hline Serv & 0.678 & 0.219 & 0.159 & -0.207 & 0.400 & 0.424 & 1.000 & & & & & & & & \\
\hline DCap & 0.147 & 0.073 & -0.130 & -0.229 & 0.053 & 0.123 & 0.137 & 1.000 & & & & & & & \\
\hline HCap & -0.021 & -0.047 & 0.145 & -0.053 & 0.073 & -0.073 & 0.077 & 0.188 & 1.000 & & & & & & \\
\hline TGap & -0.100 & -0.061 & -0.041 & 0.080 & 0.087 & -0.083 & -0.067 & -0.060 & -0.086 & 1.000 & & & & & \\
\hline Infra & 0.042 & 0.048 & 0.354 & -0.068 & 0.013 & -0.025 & 0.095 & 0.107 & 0.148 & -0.102 & 1.000 & & & & \\
\hline Lab & -0.206 & -0.208 & -0.092 & 0.345 & -0.093 & -0.202 & -0.167 & -0.231 & -0.037 & -0.038 & 0.032 & 1.000 & & & \\
\hline NRes & -0.052 & 0.031 & -0.040 & -0.022 & -0.120 & -0.094 & -0.140 & 0.270 & 0.204 & -0.257 & 0.042 & -0.014 & 1.000 & & \\
\hline PStab & -0.058 & -0.148 & 0.079 & 0.156 & 0.096 & -0.134 & -0.045 & 0.173 & 0.302 & 0.142 & 0.067 & 0.141 & 0.074 & 1.000 & \\
\hline GExp & 0.141 & 0.175 & 0.037 & 0.005 & 0.061 & 0.124 & 0.093 & -0.002 & -0.079 & 0.081 & -0.020 & 0.109 & -0.119 & -0.069 & 1.000 \\
\hline
\end{tabular}

Notes: CV = Coefficient of variation; GRW= Annual real GDP growth rate; FDI = Foreign direct investment; $\mathrm{M} \& \mathrm{~A}=$ Cross border merge and acquisition, $\mathrm{GF}=\mathrm{Greenfield}$ investment, DCap = Gross fixed capital formation; Hcap= Human capital, Tgap=Technology gap, Infra= Infrastructure, Agric = Agriculture, value added; Serv = Service, value added; Manu = Manufacturing, value added.

Where technological gap between domestic and foreign firms is large, there is an indication that local and foreign markets produce with different technologies, or different products, even though they might operate in the same sector.

Then, infrastructure is also proxied by Fixed telephone subscriptions (per 100 people) as it is commonly found in literature. It is the most common practice for empirical estimation in Africa, over energy consumption and transport network, since the latter is more likely to be inaccurate measurement for Africa [3]. Labor is the total labor force estimated as a percentage of GDP. Natural resource is employed to measure the quantity of natural resource endowment of the host country. The paper employed natural resource rent as a percent of GDP to measure natural resource variable. The natural resource variable is very necessary for this analysis because, according to the latest Africa's Pulse analysis of the continent's economy conducted by the World Bank, natural resources still account for $3 / 4$ of SSA'sexports.

It is obvious that political stability has a direct effect on FDI decisions as far as investing in Africa is concerned, therefore omitting it will cause a bias in estimating the impact of FDI on economic growth. There is a high probability that these variables have a close effect on FDI decisions, therefore omitting them will cause a bias in

ISSN: 0010-8189

(c) CONVERTER 2021

www.converter-magazine.info 
estimating the impact of FDI on economic growth. The following are the hypothesis employed to find the place of the variables listed above. I also chose the control variables based on earlier literature [11]. Finally, the size of government is proxied by government expenditure. Government expenditure is employed to investigate how much the expenditure of host country influences foreign investments. Government's illicit misappropriation of funds and lack of accountability in terms of foreign aids is a rampant phenomenon in Africa.

As mentioned earlier, this paper looks at the direct and indirect ways of foreign capital impact on the host economy. The study will investigate sectoral transfer and spillover channels by including the interaction terms: (1) M\&A and greenfield investment spillover within the various sectors (M\&A x SECT and GF x SECT). (2) the effectiveness of transmission channels such as DCap, Hcap, Lab and NRes.

The statistic description of the variables is presented in the table 4.1 above. The result of our descriptive analysis report that the mean of FDI inflow and GDP growth over the period are $5.130 \%$ and $3.884 \%$ respectively while the standard deviation of FDI is higher. For the three sectors, the highest is the service sector followed by the manufacturing then the agriculture sector. The mean of the greenfield investment variable is $3.545 \%$ which is higher compared to merge and acquisition $(0.902 \%)$. The other means $21.750 \%, 29.710 \%, 1.346$ and $2.755 \%$ for domestic investment, human capital, technology gap and infrastructure respectively. We estimated the coefficient of variation (CV) which is the measure of the level of volatility of the variables. A higher CV value signifies a higher level of volatility and vice versa. So, the results show that the service sector is the most volatile sector, and FDI seems to the most stable of all variables. Also, a positive skewness figure shows the variables are skewed to the right, implying that only the service sector is liable to skew towards the left. The descriptive analysis table shows other test results such as the correlation between the variables. We see that FDI is positively and strongly correlated with economic growth (fig. 1).

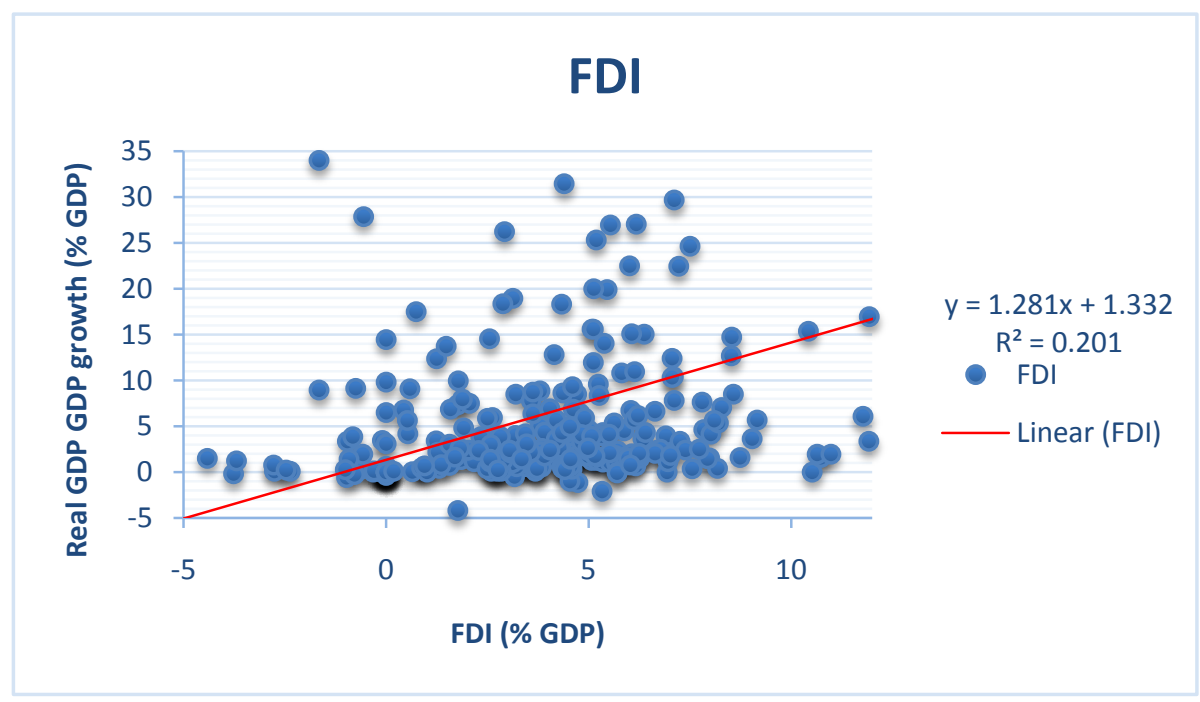

Fig1: Simple regression of FDI on economic growth

\subsection{Empirical model specification}

A growth equation in which the trajectory of economic development is determined by FDI, sectoral value-added, and other control variables, is employed here to investigatethe impact of FDI on economic growth. The equation (1) below is specifically designed to evaluated the effect FDI has on economic growth, while real GDP growth is specifically established to depend on its one-period lag.

$$
\mathrm{g}_{\mathrm{Yit}}=\gamma_{\mathrm{o}} \mathrm{g}_{\mathrm{Y}_{i t-1}}+\gamma_{1} \mathrm{FDI}_{\mathrm{it}}+\gamma_{2} \mathrm{SCT}_{\mathrm{it}}+\gamma_{3} \mathrm{X}_{\mathrm{it}}+\mu_{\mathrm{i}}+\lambda_{\mathrm{t}}+\varepsilon_{\mathrm{it}}(1)
$$

In order to determine countries' (di) convergence to a steady-level, $\mathrm{g}_{\mathrm{Y}_{i t-1}}$ is formulated to capture the real GDP growth rate and the lag growth rate. $\mathrm{g}_{\mathrm{Y}_{i t-1}}$ is the foreign direct investment inflow. $\mathrm{SCT}_{\text {it }}$ is represent the sectoral

ISSN: 0010-8189

(c) CONVERTER 2021

www.converter-magazine.info 
value-added while $\mathrm{X}$ denotes control variables like domestic investment, human capital, technological gap, infrastructure and political stability. $i$ and $t$ stand for the country and time indices. $\gamma_{1}, \gamma_{2}$ and $\gamma_{3}$ are the measurement of the direct impact of FDI and indirect impact of sectors and transmission channels on economic growth. Country-specific fixed effects is denoted as $\mu_{\mathrm{i}}, \lambda_{\mathrm{t}}$ the time effect while $\varepsilon_{\mathrm{it}}$ represent the error term.

As already mentioned, one of the targets of this research is the economic sectors in Africa, therefore the second level analysis is to find the FDI effect on the three sectors in Africa as described in the equation (2) below.

$$
\mathrm{SCT}_{\mathrm{it}}=\gamma_{\mathrm{o}} \mathrm{SCT}_{\mathrm{it}-1}+\gamma_{1} \mathrm{FDI}_{\mathrm{it}}+\gamma_{2} \mathrm{X}_{\mathrm{it}}+\mu_{\mathrm{i}}+\lambda_{\mathrm{t}}+\varepsilon_{\mathrm{it}}(2)
$$

Because M\&A and Greenfield investment are differing greatly in form and nature, we replaced FDI by its two components. Our expectation is that they have different impact on economic growth. For this analysis, we employ M\&As (MA) and greenfield investment (GF) in the regression model. Here, multiplicative terms of MA, GF and the sectoral value additions were introduced to examine the spillover of FDI in each sector and it is expressed in equation (3) below:

$$
\mathrm{g}_{\mathrm{Yit}}=\gamma_{\mathrm{og}} \mathrm{g}_{i t-1}+\gamma_{1 \mathrm{MA}} \mathrm{MA}_{\mathrm{it}}+\gamma_{1 \mathrm{GF}} \mathrm{GF}_{\mathrm{it}}+\gamma_{2} \mathrm{SCT}_{\mathrm{it}}+\gamma_{3} \mathrm{X}_{\mathrm{it}}+\gamma_{4}(\mathrm{MA}, \mathrm{GF}) * \mathrm{SCT}_{\mathrm{it}}+\gamma_{5} \mathrm{X}_{\mathrm{it}} * \mathrm{SCT}_{\mathrm{it}}+\mu_{\mathrm{i}}+\lambda_{\mathrm{t}}+\varepsilon_{\mathrm{it}}(3)
$$

Where M\&A and GF here represents Cross-border Merge and Acquisition and Greenfield investment respectively. Our interest in equation (3) is the coefficients $\gamma_{1 \mathrm{MA}}$ and $\gamma_{1 \mathrm{GF}}$ which denote the direct impact of M\&A and Greenfield investment on economic growth. The two modes of FDI are estimated separately, on one hand to provide a distinct understanding of how they individually impact the economy [19] and on the other hand to avoid multicollinearity [15]. M\&A is the most recognized mode of FDI entry. We account for (di) convergence and reveal issues of endogeneity and simultaneity by incorporating lagged economic growth in the equation because the initial condition is potentially associated with the error factor. Endogeneity can be avoided by estimating the equation with the System generalized method of moments (GMM) as described by Arellano and Bond [4] and Arellano and Bover [5]. The use of lags of explanatory variables as valid instruments was advocated by Arellano and Bond [4]. The System-GMM is used to blend a regression in the first difference estimation and regression in levels. It not only takes care of the stationarity property of the variable by using an additional moment, but it also takes care of the stationarity property of the variable by using an additional moment.

To prevent biases of our results and to arrest the influence of possible business cycles the data might contain, we used 5year averages (1990-1994, 1995-1999; ...2015-2019) making six (6) non-overlapping periods. To the extent that $\mathrm{T}=6$ and $\mathrm{N}=40$, explaining that in addition to the other advantages, GMM appropriately fits this study [4]. The efficacy of our estimations, as well as the validity of our instruments and over-identifying restriction, were tested using the serial correlation test and the DurdanWaston statistics.

\section{Empirical Results}

The results are reported and discussed in two parts in this section. The aggregate level analysis is covered in the first part. The second section focuses on the debate inside and between sectors.

\subsection{Aggregate growth effect}

First and foremost, the validation of our estimation technique's efficacy in table 2 where the efficacy of the model and instruments employed for the analysis are clearly demonstrated to be accurate.

According to our results in table2, FDI shows positive and strongly significant coefficients across board. The interpretation is that an increase FDI inflow boosts economic emancipation in Africa. It is less surprising, given FDI is known to provide a slew of value adds in the nature of capital and technology transfers, increased job creation, and increased exports, all of which are expected to stimulate growth in developing countries. Our findings are in line with several previous research on the region [11], although they are not in agreement with Adams \&Opoku [1], Agbloyor et al. [2] and Ashraf et al., [6]. Indeed, given our sample's longer time span (1990-2019), our estimations could be justified. Adams and Opoku [1] and Agbloyor et al [2] however used a very tiny sample size; 1980-2011 and 1990-2007, respectively, and worked with a much lower sample size. For example, GuiDiby

ISSN: 0010-8189

(c) CONVERTER 2021

www.converter-magazine.info 
[4] observed a negative effect off FDI on economic growth from 1980 to 1994, but a favorable effect from 1995 to 2009.

Meanwhile, the impact of M\&A and greenfield investment on economy growth is not homogenous. Overall, greenfield investment has negative and insignificant coefficients, whereas M\&A has a significant and positive impact on growth. Results reveal that, at the conventional level, as seen in column ( I), 1\%-point increase of M\&A causes 0.42 units (on average) of GDP growth in the short-term and 0.84 in the long term. Obviously, this result is not implausible. Further, the results show that a $1 \%$ rise in greenfield investment incurs a $0.22 \%$-point (average) decrease of GDP growth both at the conventional estimation. The results are identical when M\&A and greenfield investments are regressed both individually and together. When all control variables are included in the regression, FDI maintain a comparatively stronger impact on GDP growth than M\&A and greenfield investment.

The interpretation of control variables signifies those foreign investments themselves do not necessarily translate into long-term economic growth in the host country. For example, in terms of absorptive capacity in the host country (Column V \& VI), domestic capital contributes significantly to growth through foreign investment. [12] used data from developing countries, while [14] used data from Arab countries and Gui-Diby [4] used data from African countries, which is in conflict with Borensztein [12], Lui et al.; [20] and Miller [21] used data from developing countries. Obviously, human capital and domestic capital in Africa are complementary to FDI. Meanwhile, many foreign firms bring laborers from their home countries because policies in most African countries do not enforce the use of the local labor force. The results for labor show significant but negative figures across the equations.

Table2 System GMM-Focus on M\&A and greenfield Investment's effect on growth

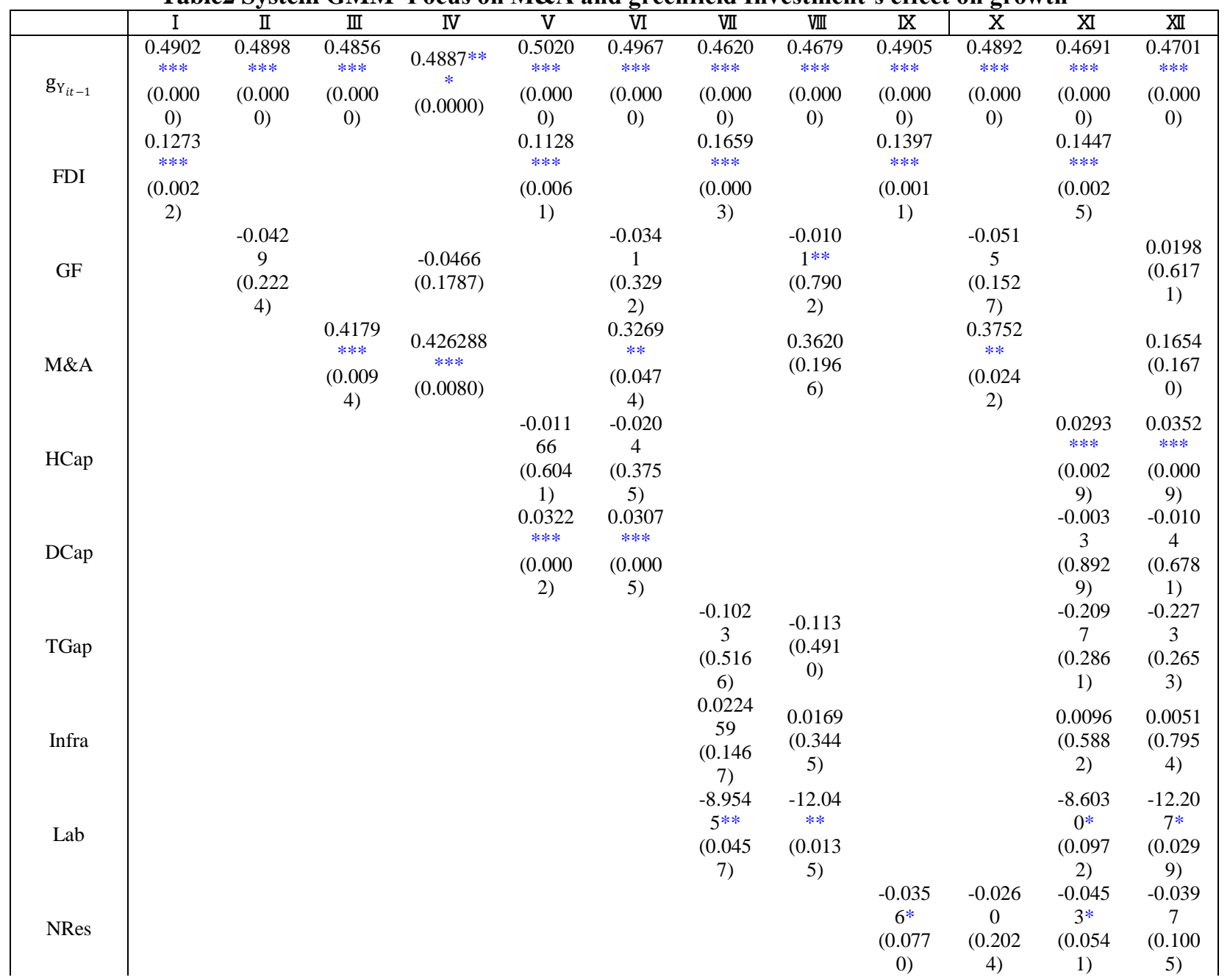

ISSN: 0010-8189

(C) CONVERTER 2021

www.converter-magazine.info 


\begin{tabular}{|c|c|c|c|c|c|c|c|c|c|c|c|c|}
\hline PStab & & & & & & & & & $\begin{array}{c}0.1378 \\
(0.512 \\
5)\end{array}$ & $\begin{array}{c}0.1353 \\
(0.527 \\
3)\end{array}$ & $\begin{array}{c}0.1445 \\
(0.522 \\
6)\end{array}$ & $\begin{array}{c}0.2481 \\
(0.282 \\
1)\end{array}$ \\
\hline GExp & & & & & & & & & $\begin{array}{c}0.0330 \\
(0.259 \\
1)\end{array}$ & $\begin{array}{c}0.0155 \\
(0.609 \\
9)\end{array}$ & $\begin{array}{c}-0.007 \\
1 \\
(0.849 \\
5)\end{array}$ & $\begin{array}{c}-0.026 \\
8 \\
(0.497 \\
6)\end{array}$ \\
\hline & $\begin{array}{c}3.3657 \\
* * *\end{array}$ & $\begin{array}{c}3.9236 \\
* * *\end{array}$ & $\begin{array}{c}3.6232 \\
* * *\end{array}$ & $3.7764 * *$ & $\begin{array}{c}2.7100 \\
* * *\end{array}$ & $\begin{array}{c}3.3124 \\
* * *\end{array}$ & $\begin{array}{c}3.1824 \\
* * *\end{array}$ & $\begin{array}{c}3.7665 \\
* * *\end{array}$ & $\begin{array}{c}3.3000 \\
* * *\end{array}$ & $\begin{array}{c}3.9385 \\
* * *\end{array}$ & $\begin{array}{c}2.7284 \\
* * *\end{array}$ & $\begin{array}{c}3.4209 \\
* * *\end{array}$ \\
\hline Constant & $\begin{array}{c}(0.000 \\
0)\end{array}$ & $\begin{array}{c}(0.000 \\
0)\end{array}$ & $\begin{array}{c}(0.000 \\
0)\end{array}$ & $(0.0000)$ & $\begin{array}{c}(0.000 \\
0)\end{array}$ & $\begin{array}{c}(0.000 \\
0)\end{array}$ & $\begin{array}{c}(0.000 \\
0)\end{array}$ & $\begin{array}{c}(0.000 \\
0)\end{array}$ & $\begin{array}{c}(0.000 \\
0)\end{array}$ & $\begin{array}{c}(0.000 \\
0)\end{array}$ & $\begin{array}{c}(0.015 \\
1)\end{array}$ & $\begin{array}{c}(0.002 \\
6) \\
\end{array}$ \\
\hline $\mathrm{R}^{2}$ & 0.4791 & 0.4547 & 0.4712 & 0.4767 & 0.5335 & 0.5236 & 0.5143 & 0.4797 & 0.4962 & 0.4854 & 0.5663 & 0.5418 \\
\hline Adj - $R^{2}$ & 0.4731 & 0.4483 & 0.4650 & 0.4676 & 0.5199 & 0.5061 & 0.4993 & 0.4603 & 0.4811 & 0.4667 & 0.5313 & 0.5008 \\
\hline $\begin{array}{c}\text { Durbin-W } \\
\text { atson }\end{array}$ & 0.9216 & 0.8956 & 0.9512 & 0.9390 & 0.7818 & 0.7565 & 0.9877 & 0.9801 & 0.9601 & 0.9470 & 0.9314 & 0.9039 \\
\hline Obs & 135 & 135 & 135 & 135 & 135 & 135 & 135 & 135 & 135 & 135 & 135 & 135 \\
\hline Countries & 35 & 35 & 35 & 35 & 35 & 35 & 35 & 35 & 35 & 35 & 35 & 35 \\
\hline
\end{tabular}

Source: Author's calculations from Eviews10

The lack of skilled labor in the African market is explicitly expressed in literature. According to the results FDIcannot count on the African labor force to be translated into economic growth. Rather the lack of adequate labor force in Africa cause foreign investment to be harmful to economic growth.

Despite being one of the world's richest continents in terms of natural resources, Africa is one of the world's poorest continents. As mentioned earlier in the section 2 of this paper, the results of this study are in conformity with literature to prove how a curse are natural resources are for Africa. Our findings as reported in table 2 can confirm the resource curse phenomenon in Africa by the negative and significant figures.

The relationship between FDI and political stability is not very clear. For example, according to Jaspersonet all and Haussmann and Fernandez-Arias there is no relationship between the two variables. However, Loree and Guisinger evaluated data on US FDI inflows for two time periods and discovered that political instability had a negative influence on FDI inflows in 1982, but has no effect in 1977. Our result indicate that Political stability coefficient is not significant and this is in line with [22-25] Jaspersonet all and Haussmann and Fernandez-Arias. Our finding is not surprising. For example, the republic of Angola in 1998 and 1999 experience a civil war however FDI inflow into the country was the highest in SSA. This scenario is best explained asFDI flow to Angola been primarily into the petroleum sector, is so profitable at the moment that the risk of investment in the country under such volatile conditions was inconsequential. This could also indicate that African been the lowest FDI inflow region in the world is due to the bad reputation the continent has accumulated over the years. Finally, the insignificant coefficients on political stability suggest that political stability in Africa does not affect much foreign investment inflow, thus political instability facilitates corruption therefore removes all forms of bureaucracy and allows foreign firms to use invest under risky conditions but with a high potential to maximize profit if things work well. Government expenditure are insignificant across board. This indicates how minimal government spending contributes to economic growth in Africa.

\subsection{Sectoral growth effect}

Our results at the sectoral level are reported in table 3 below. At face value, the contribution of FDI to economic value addition is positive across all sectors, meanwhile the impact is insignificant in the agriculture sector, weakly in the manufacturing and strong in the service sector. The impact of M\&A and greenfield investments on growth is exactly proportional to the total FDI contribution across the sectoral value addition. This means that, when compared to other sectors, investments in the service sector have a steadier impact on economic growth, implying that the service industry is a significant enhancer of economic growth in Africa, given its consistent significant coefficient $[0.1777(0.0001)$ and $0.1758(0.001)]$, respectively without and with control variables (Table3).

ISSN: 0010-8189

(C) CONVERTER 2021 
Table3 System GMM - Focus on sectoral growth effect

\begin{tabular}{|c|c|c|c|c|c|c|c|c|c|}
\hline $\begin{array}{c}\text { Depende } \\
\text { nt }\end{array}$ & \multicolumn{9}{|c|}{ Explanatory Variables } \\
\hline \multirow{4}{*}{ Agric } & I & II & III & IV & $\mathrm{V}$ & VI & VII & VIII & IX \\
\hline & $\begin{array}{c}\text { Agric }_{i t-1} \\
24.0561^{* * *} \\
(0.0000) \\
0.5166^{* * * *} \\
(0.0000)\end{array}$ & $\begin{array}{c}\mathrm{FDI}_{i t} \\
0.0291 \\
(0.5093)\end{array}$ & $\begin{array}{c}0.0063 \\
(0.8647)\end{array}$ & $\begin{array}{c}-0.0861 \\
(0.6139)\end{array}$ & $H_{C a p}$ & $D C a p_{i t}$ & $\mathrm{Lab}$ & NRes & $\begin{array}{c}\text { Constant } \\
2.8215 * * * \\
(0.0000) \\
2.9267 * * * \\
(0.0000)\end{array}$ \\
\hline & $\begin{array}{c}0.5553 * * * \\
(0.0000)\end{array}$ & $\begin{array}{c}0.0433 \\
(0.3415)\end{array}$ & & & $\begin{array}{c}0.0151^{* *} \\
* \\
(0.0000)\end{array}$ & $\begin{array}{l}-8.0670 \\
(0.9975)\end{array}$ & $\begin{array}{c}0.4607 \\
(0.9333)\end{array}$ & $\begin{array}{c}-0.050 * * \\
(0.0482)\end{array}$ & $\begin{array}{c}2.7463 * * * \\
(0.0003)\end{array}$ \\
\hline & $\begin{array}{c}0.5585 \\
(0.0000)\end{array}$ & & $\begin{array}{c}0.0161 \\
(0.6971)\end{array}$ & $\begin{array}{l}-0.2671 \\
(0.3170)\end{array}$ & $\begin{array}{l}0.01340 \\
(0.1953)\end{array}$ & $\begin{array}{c}0.0025 \\
(0.9219)\end{array}$ & $\begin{array}{l}-2.1374 \\
(0.7128)\end{array}$ & $\begin{array}{c}-0.0490 * \\
(0.0521)\end{array}$ & $\begin{array}{c}3.0176 * * * \\
(0.0000)\end{array}$ \\
\hline \multirow{4}{*}{ Manu } & $\begin{array}{c}\text { Manu }_{i t-1} \\
0.5122^{* * * *} \\
(0.0000)\end{array}$ & $\begin{array}{c}\mathrm{FDI}_{i t} \\
0.2176^{*} \\
* * \\
(0.0029)\end{array}$ & GF & M\&A & $\mathrm{HCap}_{i t}$ & $D_{C a p}$ & Lab & NRes & $\begin{array}{c}\text { Constant } \\
3.0699 * * * \\
(0.0000)\end{array}$ \\
\hline & $\begin{array}{c}0.5177 * * * \\
(0.0000)\end{array}$ & & $\begin{array}{c}-0.1264 * \\
* \\
(0.0394)\end{array}$ & $\begin{array}{c}0.4389 \\
(0.1199)\end{array}$ & & & & & $\begin{array}{c}4.0373 * * * \\
(0.0000)\end{array}$ \\
\hline & $\begin{array}{c}0.5164 * * * \\
(0.0000)\end{array}$ & $\begin{array}{c}0.2080 * \\
* * \\
(0.0081)\end{array}$ & & & $\begin{array}{l}0.0561 * * \\
*(0.0020)\end{array}$ & $\begin{array}{l}-0.0398 \\
(0.3554)\end{array}$ & $\begin{array}{l}-6.4558 \\
(0.4949)\end{array}$ & $\begin{array}{c}-0.0795 * \\
(0.0656)\end{array}$ & $\begin{array}{c}3.3888 * * * \\
(0.0088)\end{array}$ \\
\hline & $\begin{array}{c}0.5193 \\
(0.0000)\end{array}$ & & $\begin{array}{c}-0.0497 \\
(0.4913)\end{array}$ & $\begin{array}{c}0.2010 \\
(0.6658)\end{array}$ & $\begin{array}{c}0.0556^{* *} \\
* \\
(0.0037)\end{array}$ & $\begin{array}{l}-0.0500 \\
(0.2649)\end{array}$ & $\begin{array}{l}-8.9785 \\
(0.3822)\end{array}$ & $\begin{array}{l}-0.0674 \\
(0.1274)\end{array}$ & $\begin{array}{c}4.4432 * * * \\
(0.0006)\end{array}$ \\
\hline \multirow{4}{*}{ Serv } & $\begin{array}{c}\text { Serv }_{i t-1} \\
0.5196^{* * * *} \\
(0.0000)\end{array}$ & $\begin{array}{c}\mathrm{FDI}_{i t} \\
0.1777 * \\
* * \\
(0.0001)\end{array}$ & GF & M\&A & $\mathrm{HCap}_{i t}$ & $\operatorname{DCap}_{i t}$ & $\mathrm{Lab}$ & NRes & $\begin{array}{c}\text { Constant } \\
3.5059 * * * \\
(0.0000)\end{array}$ \\
\hline & $\begin{array}{c}0.5233 \\
(0.0000)\end{array}$ & & $\begin{array}{c}-0.1400 * \\
* * \\
(0.0002)\end{array}$ & $\begin{array}{c}0.5345 * \\
* * \\
(0.0019)\end{array}$ & & & & & $\begin{array}{c}4.3535 * * * \\
(0.0000)\end{array}$ \\
\hline & $\begin{array}{c}0.5411^{*} * * \\
(0.0000)\end{array}$ & $\begin{array}{c}0.1758 * \\
* * \\
(0.0001)\end{array}$ & & & $\begin{array}{c}0.0278 * * \\
* \\
(0.0054)\end{array}$ & $\begin{array}{c}0.0483 * * \\
(0.0426)\end{array}$ & $\begin{array}{l}-6.9202 \\
(0.1825)\end{array}$ & $\begin{array}{l}-0.0927 * * \\
*(0.0001)\end{array}$ & $\begin{array}{c}2.802850 * * \\
* \\
(0.0001)\end{array}$ \\
\hline & $\begin{array}{c}0.5327 * * * \\
(0.0000)\end{array}$ & & $\begin{array}{c}-0.0958 * \\
* \\
(0.0166) \\
\end{array}$ & $\begin{array}{c}0.6279 * \\
* \\
(0.0149) \\
\end{array}$ & $\begin{array}{c}0.0281 * * \\
*(0.0072)\end{array}$ & $\begin{array}{c}0.0321 \\
(0.1917)\end{array}$ & $\begin{array}{l}-5.3523 \\
(0.3374)\end{array}$ & $\begin{array}{l}-0.0800 * * \\
*(0.0011)\end{array}$ & $\begin{array}{c}3.6610 * * * \\
(0.0000)\end{array}$ \\
\hline \multirow{3}{*}{$\mathrm{g}_{\mathrm{Y}}$} & $\mathrm{g}_{Y_{i t-1}}$ & $\mathrm{FDI}_{i t}$ & & & Agric $_{i t}$ & Indus $_{i t}$ & $\operatorname{Serv}_{i t}$ & & Constant \\
\hline & $\begin{array}{c}0.1668 * * * \\
(0.0000)\end{array}$ & $\begin{array}{c}0.0117 \\
(0.6821)\end{array}$ & & & $\begin{array}{c}0.120730 \\
* * * \\
(0.0015)\end{array}$ & $\begin{array}{c}0.170849 * \\
* * \\
(0.0000)\end{array}$ & $\begin{array}{c}0.388 * * * \\
(0.0000)\end{array}$ & & $\begin{array}{c}1.1756^{* * * *} \\
(0.0000)\end{array}$ \\
\hline & $\begin{array}{c}0.1586^{* * * *} \\
(0.0000)\end{array}$ & & $\begin{array}{c}0.0358 \\
(0.1262)\end{array}$ & $\begin{array}{l}0.1890 * \\
(0.0758)\end{array}$ & $\begin{array}{c}0.1229 * * \\
*(0.0011)\end{array}$ & $\begin{array}{c}0.1737 * * * \\
(0.0000)\end{array}$ & $\begin{array}{c}0.3935 * * \\
* \\
(0.0000) \\
\end{array}$ & & $\begin{array}{c}0.9851 * * * \\
(0.0001)\end{array}$ \\
\hline
\end{tabular}

(i) The dependent variables are agriculture, manufacturing, service value added and GDP growth respectively.

(ii) Coefficients for country and time fixed effects are not reported.

(iii) $\mathrm{p}$-value are in parentheses.

(iv) $* * *, * *$ and $*$ indicate significance at the $1 \%, 5 \%$ and $10 \%$ levels

Source: Author's calculations from Eviews10

These findings are in line with [26-28] to name a few, indicating that FDI in the service sector has a positive direct and indirect influence on economic growth in Africa. Moreover, our findings support that the scope of technology transfer though foreign investment is rather advantageous to service sector, but not directly beneficial to the agriculture and manufacturing sector

However, the insignificant effect of the accumulated sectoral value addition on the overall economy is seen when foreign investment does not show any significant on growth. Evidently,FDI inflow into Africa over the years has not contributed to the industrialization of the continent, rather African manufacturing sectorisleft to compete with more advanced industrial systems from other parts of the world. Furthermore, the overall positive effect of FDI on

ISSN: 0010-8189

(c) CONVERTER 2021

www.converter-magazine.info 
economic growth across sectors is consistent with Alfaro and Aykut and Sayek's cross-country findings. We assess the robustness of our results to ensure that our findings on showing favorable direct benefits of FDI on sectoral economic growth are not influenced by potential collinearity, as Column (V) contains multiple highly correlated investment variables.

Furthermore, FDI has a little impact on agricultural growth, a moderate impact on manufacturing sector growth, and a considerable contribution to service sector growth. In similitude, M\&A and greenfield investment are both positive but insignificant in the agriculture sector. In the manufacturing sector, greenfield become weakly significant but negative while M\&A remains positive and insignificant. Then the service sector, both greenfield and M\&A become strongly significant in conformity with total FDI inflow, even though greenfield has a negative coefficient across the estimation (Table 3).

We conducted further studies to identify FDI spillover channels in the different sectors in Africa. Generally, the results in table 4 reaffirm that FDI is the best channel of advanced technology and knowledge transfer from a foreign firm into Africa. According to the results, FDI shows a strong and consistent spillover effect across all sectors [0.1301(0.0000); 0.0398(0.0000); 0.0450(0.0000)]. FDI coefficient is more significant compared to greenfield and M\&A, confirming again that greenfield and M\&A are components of FDI. Meanwhile, greenfield investment has a better spillover effect than M\&A, even though both have positive and significant figures. The coefficient of greenfield in the manufacturing and service sectors are identical while the agriculture sector is slightly less significant, though all sectors prove very significant figures [0.0943(0.0002); 0.0826(0.0000); $0.0616(0.0000)]$. M\&A has the most significant effect in industrial sector, followed by the agriculture sector then the service sector [0.1946(0.0012); 0.2266(0.0009); 0.1607(0.0249)]. Greenfield development appears to directly encourage growth in the service sector in African economies, as well as spilling over to sectors in those nations that are technologically advanced. The positive agriculture impact across all models translates into an optimistic vision of FDI in the agricultural sector in Africa.

Table4System GMM - Focus on Sectoral investment channels

\begin{tabular}{|c|c|c|c|c|c|c|}
\hline \multirow[b]{3}{*}{ Constant } & \multicolumn{2}{|c|}{ Agriculture channel } & \multicolumn{2}{|c|}{ Manufacturing channel } & \multicolumn{2}{|c|}{ Service channel } \\
\hline & \multicolumn{2}{|c|}{ I II } & \multicolumn{2}{|r|}{ II } & I & II \\
\hline & $\begin{array}{c}2.6210 * * * \\
(0.0000)\end{array}$ & $\begin{array}{c}2.8132 * * * \\
(0.0000)\end{array}$ & $\begin{array}{c}3.0067 * * * \\
(0.0000)\end{array}$ & $\begin{array}{c}3.7457 * * * * \\
(0.0000)\end{array}$ & $\begin{array}{c}3.4517 * * * \\
(0.0000)\end{array}$ & $\begin{array}{c}3.9965 * * * \\
(0.0000)\end{array}$ \\
\hline $\mathrm{SCT}_{\mathrm{it}-1}$ & $\begin{array}{c}0.3746 * * * \\
(0.0000)\end{array}$ & $\begin{array}{c}0.3568 * * * \\
(0.0001)\end{array}$ & $\begin{array}{c}0.3813 * * * \\
(0.0000)\end{array}$ & $\begin{array}{l}0.4341 * \\
(0.0000)\end{array}$ & $\begin{array}{c}0.4457 * * * \\
(0.0000)\end{array}$ & $\begin{array}{c}0.4080 * * * \\
(0.0000)\end{array}$ \\
\hline FDI & $\begin{array}{c}-0.3143 * * \\
(0.0000)\end{array}$ & & $\begin{array}{c}0.0295 \\
(0.6487)\end{array}$ & & $\begin{array}{l}-0.0276 \\
(0.6340)\end{array}$ & \\
\hline GF & & $\begin{array}{c}-0.2191 * * * \\
(0.0022)\end{array}$ & & $\begin{array}{c}-0.2485 * * * \\
(0.0000)\end{array}$ & & $\begin{array}{c}-0.2133 * * * * \\
(0.0000)\end{array}$ \\
\hline$M \& A$ & & $\begin{array}{c}-0.7150 * * * \\
(0.0000)\end{array}$ & & $\begin{array}{c}-1.0408 * * * * \\
(0.0165)\end{array}$ & & $\begin{array}{l}-0.5178 \\
(0.2317)\end{array}$ \\
\hline Spillovers & & & & & & \\
\hline FDI x SCT & $\begin{array}{c}0.1301 * * \\
(0.0000)\end{array}$ & & $\begin{array}{c}0.0398 * * * \\
(0.0000)\end{array}$ & & $\begin{array}{r}0.0450 * * * \\
(0.0000)\end{array}$ & \\
\hline GF $x$ SCT & & $\begin{array}{c}0.0943 * * * \\
(0.0002)\end{array}$ & & $\begin{array}{c}0.0826 * * * \\
(0.0000)\end{array}$ & & $\begin{array}{c}0.0616 * * * \\
(0.0000)\end{array}$ \\
\hline $\mathrm{M} \& \mathrm{~A} \times \mathrm{SCT}$ & & $\begin{array}{c}0.1946 * * * \\
(0.0012)\end{array}$ & & $\begin{array}{c}0.2266 * * * \\
(0.0009)\end{array}$ & & $\begin{array}{c}0.1607 * * \\
(0.0249)\end{array}$ \\
\hline $\mathrm{R}^{2}$ & 0.6722 & 0.6212 & 0.7406 & 0.7305 & 0.5583 & 0.5948 \\
\hline Adj - $R^{2}$ & 0.6665 & 0.6100 & 0.7361 & 0.7225 & 0.5505 & 0.5828 \\
\hline Durbin-Watson & 1.4164 & 1.1628 & 1.3824 & 1.2086 & 1.1446 & 1.0719 \\
\hline Obs & 135 & 135 & 135 & 135 & 135 & 135 \\
\hline Countries & 35 & 35 & 35 & 35 & 35 & 35 \\
\hline
\end{tabular}

Source: Author's calculations from Eviews10

Our findings confirm that FDI inflows in Africa form the best diffusion channels in no other than the manufacturing sector. Greenfield development appears to directly encourage growth in the service sector in African economies, as well as spilling over to sectors in those nations that are technologically advanced. Unsurprisingly, this trend of describing Africa as a continent in lack of industrialization has been in existent for decades now [4]. In

ISSN: 0010-8189

(C) CONVERTER 2021

www.converter-magazine.info 
terms of FDI growth through the agricultural sector, our findings confirm consistent insignificantly positive coefficients of the interaction terms.

\section{Robustness}

We re-estimated the fundamental equation (1) in two ways to test the resilience of our model. To begin, the dependent variable is GDP per capita growth.Second, fixed and random effects are evaluated for dynamic panels, as proposed by Blundell and Bond. In the FDI-growth literature, this strategy has gained appeal as a way to address the Nickell bias, as well as the endogeneity problem and measurement inaccuracy.

In general, when compared to the main analysis's estimation of real GDP growth, the robust check's GDP per capita growth yields values that are consistent with our findings.In particular, we continue to see a positive and statistically significant effect of FDI on growth, while the amount of the difference is statistically negligible. The situation is consistent with the concept that absorptive ability in the host country is critical for FDI transmission.

At this level, absorptive capacity is further examined in order to investigate the best conducive environment for economic transformation for Africa's economic emancipation. According to Balasubramanyam et al. [23], discussing the FDI-growth effect naturally involves prior investment in the domestic market. Domestic investment mainly contributes to physical accumulation in the host country. It also allows for a comparison between the contribution of two investment sources (foreign and domestic) to the growth process.

Table 5 GDP per capita (Robust check)

\begin{tabular}{|c|c|c|c|c|c|c|}
\hline & (I) & (II) & (III) & (IV) & $(\mathrm{V})$ & (VI) \\
\hline Constant & $\begin{array}{c}0.8804 * * * \\
(0.0000)\end{array}$ & $\begin{array}{c}1.4992 * * * \\
(0.0000)\end{array}$ & $\begin{array}{c}1.1293 * * * \\
(0.0000)\end{array}$ & $\begin{array}{c}1.3606 * * * \\
(0.0000)\end{array}$ & $\begin{array}{c}1.7409 * * * \\
(0.0054)\end{array}$ & $\begin{array}{c}2.1003 * * * \\
(0.0006)\end{array}$ \\
\hline$g_{Y-1}$ & $\begin{array}{c}0.4942 * * * \\
(0.0000)\end{array}$ & $\begin{array}{c}0.5005^{* * * *} \\
(0.0000)\end{array}$ & $\begin{array}{c}0.4891 * * * \\
(0.0000)\end{array}$ & $\begin{array}{c}0.4993 * * * * \\
(0.0000)\end{array}$ & $\begin{array}{c}0.5033 * * * \\
(0.0000)\end{array}$ & $\begin{array}{c}0.4960 * * * \\
(0.0000)\end{array}$ \\
\hline FDI & $\begin{array}{c}0.1213 * * * \\
(0.0018)\end{array}$ & & & & $\begin{array}{c}0.0937 * * \\
(0.0139)\end{array}$ & \\
\hline GF & & $\begin{array}{c}-0.0670 * * \\
(0.0418)\end{array}$ & & $\begin{array}{c}-0.0704 * * \\
(0.0298)\end{array}$ & & $\begin{array}{l}-0.0069 \\
(0.8414)\end{array}$ \\
\hline M\&A & & & $\begin{array}{c}0.3884 * * * \\
(0.0099)\end{array}$ & $0.4008 * * *(0.0072)$ & & $\begin{array}{l}0.4368^{*} \\
(0.0491)\end{array}$ \\
\hline HCap & & & & & $\begin{array}{c}0.0317 * * * \\
(0.0003)\end{array}$ & $\begin{array}{c}0.0343 * * * \\
(0.0002)\end{array}$ \\
\hline DIin & & & & & $\begin{array}{l}-0.0124 \\
(0.5493)\end{array}$ & $\begin{array}{l}-0.0228 \\
(0.2827)\end{array}$ \\
\hline Lab & & & & & $\begin{array}{c}-13.247 * * * \\
(0.0040)\end{array}$ & $\begin{array}{c}-14.368 * * * \\
(0.0035)\end{array}$ \\
\hline NRes & & & & & $\begin{array}{c}-0.0694 * * * * \\
(0.0010)\end{array}$ & $\begin{array}{c}-0.0628 * * * \\
(0.0030)\end{array}$ \\
\hline $\mathrm{R}^{2}$ & 0.4586 & 0.4407 & 0.4488 & 0.4639 & 0.5752 & 0.5679 \\
\hline Adj - $R^{2}$ & 0.4523 & 0.4342 & 0.4424 & 0.4545 & 0.5556 & 0.5444 \\
\hline Durbin-Watson & 0.8732 & 0.8641 & 0.9020 & 0.9024 & 0.9483 & 0.9393 \\
\hline Obs & 135 & 135 & 135 & 135 & 135 & 135 \\
\hline Countries & 35 & 35 & & 35 & 35 & 35 \\
\hline $\begin{array}{l}\text { otes: } \\
\text { The dependent } \\
\text { ) AR (1): Arellan } \\
\text { i) p-value are in } \\
\text { v) } * * *, * * \text { and } * \text { i }\end{array}$ & $\begin{array}{l}\text { ond ( } 1 \\
\text { eses. } \\
\text { signifi }\end{array}$ & the $1 \%$ & nd $10 \%$ & & & \\
\hline
\end{tabular}

\section{Source: Author's calculations from Eviews 10}

When all variables are controlled, the effects of human capital on growth remains positive and robust. This effect is resilient to all model settings, confirming the evidence that well-developed domestic sectors boost economic growth in a variety of ways, depending on their activities and chances for knowledge and skill transfer [17, 29-31].This implies that human capital can be a bait for foreign investment inflow and at the same time getting access to capital equipment to promote development in Africa.

ISSN: 0010-8189

(C) CONVERTER 2021

www.converter-magazine.info 
Re-estimating equation (1) using the fixed and random effects, as presented by Blundell and Bond for dynamic panels, is another sensitivity analysis. Both a fixed-effects model and a dynamic model with random effects are estimated to address the Nickell bias. Table 6 shows the outcomes of the estimation. In line with past findings in table2, M\&A is confirmed to be more beneficial.than greenfield, even though greenfield investment in this case seems to have a stronger impact on economic growth as compared to the original estimation. Especially, the strong effect FDI on growth is constant and more obvious than greenfield and M\&A.

Table 6Fixed and Random effect (Robust check)

\begin{tabular}{|c|c|c|c|c|c|c|c|c|}
\hline & \multicolumn{4}{|c|}{ Dynamic model with fixed effect } & \multicolumn{4}{|c|}{ Dynamic model with random effect } \\
\hline & ( I) & ( II) & (III) & (IV) & ( I) & ( II) & (III) & (IV) \\
\hline Constant & $\begin{array}{c}3.2026 * * * \\
(0.0000)\end{array}$ & $\begin{array}{c}4.0895 * * * \\
(0.0000)\end{array}$ & $\begin{array}{c}3.6233 * * * \\
(0.0000)\end{array}$ & $\begin{array}{c}3.9243 * * * \\
(0.0000)\end{array}$ & $\begin{array}{c}3.3120 * * * \\
(0.0000)\end{array}$ & $\begin{array}{c}3.9703 * * * \\
(0.0000)\end{array}$ & $\begin{array}{c}3.6233 * * * \\
(0.0000)\end{array}$ & $\begin{array}{c}3.8160 * * * \\
(0.0000)\end{array}$ \\
\hline$g_{Y-1}$ & $\begin{array}{c}0.4910 * * * \\
(0.0000)\end{array}$ & $\begin{array}{c}0.4931 * * * \\
(0.0000)\end{array}$ & $\begin{array}{c}0.4835 * * * \\
(0.0000)\end{array}$ & $\begin{array}{c}0.4903 * * * \\
(0.0000)\end{array}$ & $\begin{array}{c}0.4904 * * * \\
(0.0000)\end{array}$ & $\begin{array}{c}0.4906 * * * \\
(0.0000)\end{array}$ & $\begin{array}{c}0.4835 * * * \\
(0.0000)\end{array}$ & $\begin{array}{c}3.8160 * * * \\
(0.0000)\end{array}$ \\
\hline FDI & $\begin{array}{c}0.1775 * * * \\
(0.0004)\end{array}$ & & & & $\begin{array}{c}0.1439 * * * \\
(0.0008)\end{array}$ & & & \\
\hline GF & & $\begin{array}{c}-0.0924 * * \\
(0.0412)\end{array}$ & & $\begin{array}{l}-0.0871 * \\
(0.0518)\end{array}$ & & $\begin{array}{l}-0.0569 \\
(0.1224)\end{array}$ & & $\begin{array}{l}-0.0578 \\
(0.1125)\end{array}$ \\
\hline M\&A & & & $\begin{array}{c}0.4181 * * \\
(0.0373)\end{array}$ & $\begin{array}{c}0.3954 * * \\
(0.0469)\end{array}$ & & & $\begin{array}{c}0.4180^{* *} \\
(0.0124)\end{array}$ & $\begin{array}{c}0.4208 * * \\
(0.0116)\end{array}$ \\
\hline $\mathrm{R}^{2}$ & 0.6383 & 0.6160 & 0.6165 & 0.6270 & 0.5121 & 0.4842 & 0.4936 & 0.5030 \\
\hline Adj - $R^{2}$ & 0.5440 & 0.5158 & 0.5164 & 0.5262 & 0.5064 & 0.4782 & 0.4877 & 0.4943 \\
\hline Durbin-Watson & 1.3601 & 1.2622 & 1.3155 & 1.3013 & 1.0725 & 1.0171 & 1.0656 & 1.0616 \\
\hline Obs & 135 & 135 & 135 & 135 & 135 & 135 & 135 & 135 \\
\hline Countries & 35 & 35 & 35 & 35 & 35 & 35 & 35 & 35 \\
\hline
\end{tabular}

Notes:

(i) The dependent variable is GDP Growth.

(ii) AR (1): Arellano and Bond (1991) test for first-order autocorrelation.

(iii) $\mathrm{p}$-value are in parentheses.

(iv) $* * *, * *$ and $*$ indicate significance at the $1 \%, 5 \%$ and $10 \%$ levels.

Source: Author's calculations from Eviews10

The fixed effect results show that M\&A investment is positive and significant at $10 \%$, while FDI is significant at $1 \%$. As a result, while foreign direct investment (FDI) has a strong tendency to drive growth in Africa, domestic investment has not been a critical factor in the African growth process, and this trend is consistent in both fixed and random effect regressions (Table 6). This could be attributed to Africa receiving such a little percentage of FDI. Africa's FDI inflows have been underwhelming, indicating a situation of global financial marginalization.Furthermore, FDI flows into Africa have been skewed toward the extractive industry. The skewed flow of FDI into the extractive industry shows foreign investors' rent-seeking behavior and is largely to blame for Africa's economy's lack of diversification [19, 31].

Besides, on a number of observations for statistical testing, there is a possibility of a number of limitations in the examination. There is the limitation of missing data which may generate variable biases in statistical testing. However, we have addressed this limitation as one of the advantages of panel data analysis used in this study which is already explained above (section 3.2), thus to cope better with unbalanced data. Many researches do their best to determine and analyze the impact of modes of investment on economic growth, however this study addresses the issue of foreign investment into Africa and its implication on economic growth at the aggregate and sectoral level by including other factors ranging from market, resources, efficiency, policy, with reference to measurements applied from a combination of existing framework and previous researches. We recognize that there might be other variable measurements and other factors, which have been overlooked in this study that potentially play role as key determinants of economic growth in African countries. Lastly, this study fails to include all African countries due to serious lack of data in some countries.

ISSN: 0010-8189

(C) CONVERTER 2021

www.converter-magazine.info 


\section{Conclusion}

This study aims to find the effect of FDI on sectoral growth in Africa. A sample size of 35 African countries from 1990 to 2019 was employed for the analysis. Agriculture, manufacturing, and the service sector are the three main industries included in the research. Even while Africa's share of global FDI inflows is low in comparison to other areas, FDI inflows into Africa have been increasing for the past 20 years, with the highest levels recorded in 2001 and 2008, which also happened to be the years when most multinational collaborations took place. This justifies the time frame of our study where most African countries privatized their state-owned enterprises, known as the privatization and post-privatization era in Africa [1].

As indicated in the literature, FDI does not always translate into economic growth especially in developing countries unless the host country possesses a strong absorptive capacity. Many studies worked on FDI impact on economic growth at the aggregate level. However, study on FDI effect at the sectoral level is limited and none of these works focuses on Africa. Moreover, the mode of foreign investment entry in African sectors is completely missing in the literature. The goal of this study was to look into the influence of FDI on sectoral growth, as well as the various effects of M\&A and greenfield investment on African economic growth.

To achieve the goals, we used Blundell and Bond's System-GMM estimation to analyse FDI-GDP growth as a blueprint to show the effect of FDI on economic growth in three African sectors.

GDP growth is the study's dependent variable, which is defined as an annual percent GDP growth rate. To estimate our model, we created FDI, which represents net FDI inflow, control variables, and interaction terms. We created a panel data of 35 African countries spanning 1990 to 2019 using data from the World Bank and the United Nations Conference on Trade and Development database.

After performing the regressions, we discovered that FDI is confirmed to increase economic growth in Africa at the aggregate level. The effects of different types of foreign investment (mergers and acquisitions and greenfield investment) on the economy are not the same. While M\&A is reported to be a strong economic booster, greenfield investment on the contrary is confirmed to be unbeneficial to the African economic. At the sectoral level, foreign investment is a significant agent of economic growth in the service sector, relatively weak in the manufacturing sector and insignificant in the agriculture sector.

The level of absorptive capacity in the host domestic market has been shown to influence the impact of FDI on host countries. In comparison to domestic capital, we discovered that human capital fosters economic growth in Africa more effectively.As confirmed in literature, the education quality and skilled labor are on high demand in the foreign firms, however, they are mostly unavailable in Africa. Furthermore, many foreign firms import skilled labor. This scenario explains the negative coefficients of labor at the aggregate level. Moreover, policies in most African countries that do not enforce the use of the local labor force.

While greenfield investmentexhibits a strong and consistent spillover in all sectors, M\&A is best in the manufacturing sector but weak in the agriculture and service sectors. It is confirmed that natural resources are not very good transmission channels of foreign investments translating into economic growth.

In conclusion, this research suggests that FDI enhances economic growth in the host nation, depending on the level and quality of the host country's absorptive ability at both the aggregate and sectoral levels.Overall, M\&A is found to have more impact on economic growth in Africa than greenfield investment, with the service sector being the best beneficiary.

\section{References}

[1] Adams, S., \&Opoku, E. E. O. (2015). FDI, regulations and growth in SSA. Economic Analysis and Policy, 47, 48-56. doi: 10.1016/j.eap.2015.07.001

[2] Dunning, J. H. (2000), 'The Eclectic Paradigm as an Envelope for Economic and Business Theories of MNE Activity', International Business Review, 9, 2, 163-190

[3] Basu, P., Chakraborty, C., \&Reagle, D. (2003). Liberalization, FDI, and Growth in Developing Countries:

ISSN: 0010-8189

C CONVERTER 2021

www.converter-magazine.info 
A Panel Cointegration Approach. Economic Inquiry, 41(3), 510-516.

[4] Gui-Diby, S. L. (2014). Impact of FDI on Economic Growth in Africa: Evidencefrom Three Decades of Panel Data Analyses. Research in Economics, 2014; 3 (68): 48- 256.

[5] Doytch, N., and M. Uctum. 2011. "Does the Worldwide Shift of FDI from Manufacturing to Services Accelerate Economic Growth? A GMM Estimation Study." Journal of International Money and Finance 30 (3): 410-427.

[6] Kugler, M. 2006. “Spillovers from Foreign Direct Investment: Within or Between Industries?” Journalof Development Economics 80 (2): 444-477.

[7] Songwe, V., and K. Deininger. 2009. "Foreign Investment in Agricultural Production: Opportunities and Challenges." Agricultural and Rural Development Notes: Land Policy and Administration 45. Washington, DC: World Bank.

[8] UNCTAD. World Investment Report 2014: Investing in the SDCs-An Action Plan. New York and Geneva: United Nations Conference on Trade and Development, United Nations, 2014.

[9] FAO. 2013. Trends and Impacts of Foreign Investment in Developing Country Agriculture: Evidence from Case Studies. Rome: FAO.

[10] Asiedu, Elizabeth. On the Determinants of Foreign Direct Investment to Developing countries: Is Africa Different? World Development, 2002, 30(1); 107-119.

[11] Asiedu, Elizabeth, and Donald Lien. Democracy, Foreign Direct Investment andNatural Resources, Journal of International Economics, 2011, (84); 99-111.

[12] Borensztein, E., De Gregorio, J., \& Lee, J. (1998). How does foreign direct investment affect economicgrowth? Journal of International Economics, 45 (1), 115-135.

[13] Carkovic, M. and R. Levine (2005), 'Does Foreign Direct Investment Accelerate Economic Growth? inT. H. Moran, E. M. Graham and M. Blomstr€om (eds.), Does Foreign Direct Investment PromoteDevelopment? (Washington, DC: Institute for International Economics), 195-220.

[14] El-wassal, K. A. 2012. "Foreign Direct Investment and Economic Growth in Arab Countries(1970-2008): An Inquiry into Determinants of Growth Benefits." Journal of Economic Development37 (4): 79-100.

[15] Herzer, D., S. Klasen, and D. F. Nowak-Lehmann. 2008. "In Search of FDI-led Growth inDevelopingCountries: The way Forward.” Economic Modelling 25 (5): 793-810.

[16] Agbloyor, E. K., Abor, J. Y., Adjasi, C. K. D., \&Yawson, A. (2014). Private capital flows and economic growth in Africa: The role of domestic financial markets. Journal of International FinancialMarkets, Institutions and Money, 30(1), 137-152. doi: 10.1016/j.intfin.2014.02.003

[17] Ibrahim, M., \&Alagidede, P. (2016). Effect of financial development on economic growth in sub-Saharan Africa: Does sectoral growth matter? 1st African Review of Economics and Finance Conference, August 11-12, KNUST, Kumasi, Ghana.

[18] Ashraf, A. and D. Herzer (2014), 'The Effects of Greenfield Investment and M\&As on DomesticInvestment in Developing Countries', Applied Economics Letters, 21, 14, 997-1000.

[19] Wang, M. and Wong, M. C. S. What Drives Economic Growth? The Case of Cross Border M\&A and Greenfield FDI Activities, Kyllo’s, 2009, (62); 316-330.

[20] Liu, Xiaming, Pamela Siler, Chengqi Wang and Yingqi Wei. Productivity Spillovers from Foreign Direct Investment: Evidence from UK Industry Level Panel Data. Journal of International Business Studies, 2000, (31); 407-425.

[21] Miller, S. M., and Upadhyay, M. P. The effects of openness, trade orientation, and human capital on total factor productivity. Journal of Development Economics, 2000, (63); 399-423.

[22] Balasubramanyam, V., Salisu, M., \&Sapsford, D. (1996). FDI and growth in EP and IS countries. Economic Journal, 106, 92-105.

[23] Balasubramanyam, V. N., S. Mohammed, and D. Sapsford. 1996. "FDI and Growth in EP and IS Countries." Economic Journal 106 (1): 92-105.

[24] Chakraborty, C., \&Nunnenkamp, P. (2008). Economic reforms, FDI and economic growth in India: a sector level analysis. World Development, 36(7), 1192-1212.

De Mello Jr, L. R. 1999. "FDI-led Growth: Evidence from Time Series and Panel Data." Oxford Economic Papers 51 (1): 133-151.

[25] Herzer, D. 2012. "How Does Foreign Direct Investment Really Affect Developing Countries" Growth?" Review of International Economics 20 (2): 396-414.

[26] Lensink, R., and O. Morrissey. 2006. "Foreign Direct Investment: Flows, Volatility, and the Impact on Growth." Review of International Economics 14 (3): 478-493.

[27] World Bank. Investing Across Borders: Indicators of foreign direct investment regulations in 87

ISSN: 0010-8189

(C) CONVERTER 2021 
economies. Washington, D.C: The World Bank Group. 2010.

[28] Burrill, D. 2007. Modelling and interpreting interactions in multiple regression, Internet. Available at http://www.minitab.com.

[29] Findlay, R. (1978), 'Relative Backwardness, Direct Foreign Investment, and the Transfer of Technology: A Simple Dynamic Model', Quarterly Journal of Economics, 92, 1, 1-16.

[30] Levine, R. (1997). Financial development and economic growth: Views and agenda. Journal of Economic Literature, 35(2), 688-726. Retrieved from http://www.jstor.org/stable/2729790

[31] Roodman, D. 2009b. "A Note on the Theme of too Many Instruments." Oxford Bulletin of Economicsand Statistics 71: 135-158. 